\title{
POESIA E ARTES POÉTICAS
}

\section{Guilhermino Cesar}

Publicamos, a seguir, a Aula Magna proferida em março de 1966, na Faculdade de Filosofia da Universidade Federal do Rio Grande do Sul, pelo seu professor catedrático de Literatura Brasileira.

Antes de ler êste trabalho, explicou o $A$. que nêle fizera uma sintese de suas investigações sôbre diversas Artes Poéticas, formuladas em nossa lingua, desde o aparecimento do Barroco, pelos próprios poetas, tanto no Brasil como em Portugal.

A exemplificação oferecida teve caráter seletivo.

Nota da Redação

$\mathrm{Na}$ impossibilidade de definir a Poesia, recuso-me principalmente a considerá-la como o oposto do Real, se o Real fôr aquilo que nega o aparente, o imaginário, o ilusório, como quer a Filosofia.

Importa, então, perguntar: Realidade e Poesia são têrmos antitéticos, como luz e sombra, branco e prêto? Responda quem quiser. Só sei que Poesia e Realidade se conjugam, no plano da criação, - único plano que por ora nos interessa, - para explicar a mesma realidade que é o homem e, através dêste, o feio mundo que nos rodeia.

Jamais, como nos tempos modernos, foi tão intensa a preocupação do artista em deslindar o conteúdo - oponente ou concordante - de Realidade e Poesia, o qual importa nuclearmente à economia da obra de arte, nos liames mais sutis que aproximam ambos os têrmos e, por conseguinte, tendem à representação, à estrutura, à elaboração do objeto artístico.

Aristóteles, com a sua malícia de grego, se advertira do êrro acidental a que pode ser conduzida a poesia. Diz êle: "Pois falta menor comete o poeta que ignora que a corça não tem cornos, que o poeta que a represente de modo não artístico". ${ }^{1}$ E Johannes Pfeiffer, insistindo na só importância, para

1 - Aristóteles, Poética (Trad. de Eudoro de Sousa). Lisboa, Guimarães \& Cia., s/d., p. 119. 
o caso, do "fulgor" artístico, escreve: "Quem capte a verdade poetlea de modo racional, vendo nela uma figuração atrativa de conceitos intelectuais, converterá a poesia em algo substiluivel. Quem considere a beleza poética do ponto de vista exterlor, como uma solução feliz de certos problemas artesanais, fara da poesia algo superficial. A verdadeira poesia - conelui - nâo é veraz no sentido intelectual, nem é bela no sentido do artesanato; mas, pela circunstância de "plasmar belamente", ¿ também um modo de apoderar-se da verdade". 2

Onde está, pois, a poesia que procuramos? A resposta só pode ser esta: nas palavras do poeta que alcança a beleza, embora pinte a corça com chifres; na obra de arte que plasmou belamente, embora fugindo à realidade apreendida pela inteliHencla lógica. E aqui já é tempo de citarmos Benedetto Croce. 0) Frande crítico italiano, após dizer que a poesia é antes de 11 de "transfiguração do sentimento, não o próprio sentimento", recorda a palavra de Goethe, "que não se cansou nunca de reIiefir que tôda poesia é "poesia de ocasião", podendo a realidadi upenas fornecer-lhe o incentivo e a matéria".

Vendo-se viver, o homem se pergunta o porquê da vida. filierroga, em primeiro lugar, o ser que êle próprio é; após, inİiraga as cousas circundantes, e só neste momento - diante (lo que está do lado de fora do campo subjetivo, - só então toma contato com outra realidade, que, no caso, figura o alvo раға o qual tende a arte elaborada, enquanto produto à esпеті de consumidor.

Ouso dizer que nesse ponto de intersecção, - o Artista ein face dos outros - é que se dá também o atrito, a colisão; Hu e Nđo $E u$ são duas faces de uma só Realidade com $R$ grande, polidimensional. O encontro dessas duas linhas de fôrça é a eondiçăo mesma da vida espiritual e, portanto, da produção di Beleza, para não dizer mais clàssicamente: da ideação, na qual se contém o poder criador do homem em todos os seus elementos essenciais. É nesse ponto de atrito que se dá tambอ̉m a fusăo, pelo sentimento, do homem com a realidade conlingente, pois viver não é mais do que lutar com o Universo, dentro do qual procuramos explicação para o objetivo como рата o subjetivo. Caminhamos ansiosos, de bracos pensos, gemendo, no sentido pascaliano da busca, porque o impacto do Universo sobre o Eu desperta ressonâncias cruciais, associacôt inumeráveis, que as palavras, primeira realidade plantada nо Aิврего caminho do poeta, são insuficientes para exprimir.

1. Johannes Pfeiffer, La Poesia. México, Fonde de Cultura, 1951, pp. $100=107$

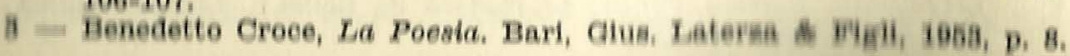

Daqui nasce o mistério da poesia, a sua linguagem cifrada, ou o seu signo, para ficarmos bem comportados ao pé de Saussure, pai da Estilística. Significante, significado, ou, somando-os, Signo - qualquer que seja o têrmo escolhido, o que está em jôgo é a mesma criação verbal, que exige, por isso, do sujeito criador, mais do que inteligência, sensibilidade. Obtém-se, desta forma, uma trans-linguagem, que as crianças e os loucos, por igual, e principalmente, compreendem. Rimbaud e Hölderlin sabem o que nós queremos dizer.

$$
* * *
$$

Mas é curioso como o Renascimento, fiel a Aristóteles, à teoria da "imitação", tanto quanto, no plano da existência, ao hedonismo, se conservou quase alheio à teorização da arte. Satisfez-se com a lição de Quintiliano, e de poucos mais. No lim do século XVI, entretanto, a estética barrôca traça novos caminhos à pesquisa, revê o cânon poético, encaminhando o lirismo, por exemplo, à revalorização das metáforas.

Pois bem. A poesia brasileira, como todos sabem, começa a existir com os autores do período barroco. É acentuadamente na direção de Luís de Góngora que se pronunciam os primeiros autores nascidos no Brasil, aquêles com os quais começam a aparecer as diferenciações - estèticamente válidas - de tema, de gôsto, de preferência vocabular. Ao "estilo jesuítico", nas artes plásticas, correspondeu assim, no quadro literário, a busca de formas gongorizantes. Mas o barroco braslleiro é um surto tardio - ocorre depois de em Portugal se terem esgotado as afetaç̃es da Academia dos Singulares e da Aeademia dos Generosos. Salvo Gregório de Matos, cuja obra fleou pràticamente inédita até o início do século XIX, os outros poetas nossos, a exemplo do que em primeiro lugar publicou livro - Manuel Botelho de Oliveira, - só aparecem impressos no século XVIII.

Entretanto, é já nesses autores que vamos encontrar a primeira "arte poética" conscientemente elaborada. O citado Manuel Botelho de Oliveira, por exemplo, assume posição nitidamente barrôca no poema intitulado Itha de Maré (1705):

Por um e outro lado

Vários lenhos se veem no mar salgado;

Uns vdo busoando da oidade a via,

Outros dela se väo eom alegria; 
E na desigual ordem

Consiste a fermosura na desordem. "

Nestes versos finais:

E na desigual ordem

Consiste a fermosura na desordem

Ge contêm um cânone artístico, justamente o que nos dá a chave da poesla de Góngora, no passado, como a de um Fernando Pessoa, no presente, e até mesmo a de um Jorge de Lima, o impuloso barroquista da Invenção de Orfeu (1952).

Que chave é esta?

A resposta parece achar-se na concepção estilistica de Dámaso Alonso, como na interpretação poética de Carlos Bousoño. 1'orque o certo é que todo o mistério poético não passa de um negredo de Polichinelo, reduzindo-se, em última instância, a um problema de "colocação". O poeta barroco da Bahia, antel eltado, sabia disto e logo o proclamou:

\section{E na desigual ordem \\ Consiste a fermosura na desordem.}

Nî́o faltou, portanto, quem nos lembrasse muito cedo que todo o problema da poesia vem da palavra, o que é tanto mais exato quanto sabemos que a nossa primeira fragilidade, ao manlpularmos o verso, resulta da impotência verbal. E impotêncli verbal não é pobreza de têrmos - porque então haveria a remédio infalivel dos dicionários - mas de "associações" efielentes, susceptiveis de comover e convencer.

Talvez fôsse mais exato repetir que as palavras, sòzinhas, nâo bastam para exprimir o que desejamos normalmente comunicar. Por mais feliz que seja o resultado de tal operação associar, friccionar palavras - o artista consciente percebe que fien sempre alguma cousa por dizer - um campo nebuloso onde a poesia ostenta, paradoxalmente, o seu maior encanto. He tudo dissesse, se tudo desvendasse, seria então outra cousa conhecimento lógico, forma destinada a esvaziar a palavra di 14 Imanencia afetiva, de ordem intuicional, e não o prisma que atende, na multiplicidade da côr, aos diversos tipos de senlibilidade existentes no sujeito consumidor de poema.

4 Manuel Botelho de Oliveira, Mussioa do Parmana. (10d, organizada e prefaciada por Antenor Nacentea), He de Ianelre, losi, Tomo $\mathbf{I}$, D. 186.
Wladimir Weidlé, estudando o divórcio entre a linguagem literária e a linguagem corrente, depois de dizer que as mais leves alterações no patrimônio de uma língua influem necessàriamente o destino da poesia, glosa o crítico italiano Chiarini, que "expôs de maneira clássica esta idéia: um grande poeta encontra melhores condições para o desenvolvimento de seu gênio se vive numa época em que a língua literária empregada por êle se encontra ainda na infância". ${ }^{5}$

$\mathrm{E}$ afirma em seguida:

"E muito natural que essa idéia haja sido defendida por um italiano, pois, de fato, quase se pode dizer que a literatura começa na Itália com o maior de seus poetas; por outro lado, um grego também poderia compartir essa opinião, e, se a corrige comparando as épocas de juventude de uma língua com aquelas em que nela se produz uma transformacão verdadeiramente profunda, poder-se-á aplicá-la a tôdas as literaturas, quer se trate de um Shakespeare ou dos poetas da Pléiade francesa, de um Goethe na Alemanha ou de um Puchkine na Rússia. Na obra de Dante, na de Shakespeare, nos poemas da juventude de Goethe, e igualmente nos de Puchkine, a criação poética coincide sempre, em certa medida, com a criação lingüistica; o idioma que forjam ainda está virgem, encerra promessas infinitas; o mesmo se dá no concernente à prosa de Montaigne, à de Lutero e à dos tradutores da Bíblia inglêsa de 1611". ${ }^{6}$

Seja como fôr, não é pela temática, mas pela renovação da linguagem, que se denuncia em substância o advento de uma escola literária, ou seja, a mudança da forma de ataque à realidade, cousa que só os artistas excepcionalmente bem dotados eonseguem atingir.

O Renascimento, já o vimos, voltou ao conceito aristotélico da imitação da natureza, mas a fôrça propulsora da Idade Mİdia, a elaboração subjacente aí assinalada, fizeram impossível a restauração integral daquele principio da era clássica.

E surgem os novos bárbaros: os românticos. São êles, agora, quem desfia a contextura da grande incógnita; debrucam-se sobre seu corpo esquivo, ondulante, e o sentimento realiza o milagre de compreender melhor o que até então se ocultavn sob o verniz da poderosa poética dos clássicos. E a primelra revoluçăo dos enfants du siècle é a das metáforas, do elemento básico, denotador, na literatura grega e na latina, da infancla da poesia no Ocidente. Quando Homero, descrevendo a

5 Wiadimir Weidlé, Wusayo sobre el Destino atual do las Letras y lia Artea, Huenos Aires, Emece, 1049, D. 110.

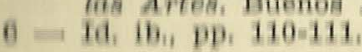


alvorada, falou em "dedos róseos" da Aurora, fêz mais do que antropomorfizar a luz matutina: criou uma fórmula à vida de representação, idealizou o simples fenômeno da influição solar num mito ... poético. As hipérboles esbraseadas da fase romântica pretenderam subir mais alto, na escala da sugestão, criando nôvo plano "ilógico", em que tôda poesia se renova.

Mas, antes dos românticos, os árcades, menos imaginosos tue Luis de Góngora e seus discipulos, regrediram à mimese clássica, com as suas sanfoninhas, os seus falsos pastôres, os neus cajados de papelão. Mas houve um dêles, Tomás Antônio Gonzaga, com algum espírito inovador. Pelo menos, o bemamado de Marília é o autor que, no pastoralismo brasileiro, mals evidencia suas ligações ideológicas com o Iluminismo, de im lado, e o nascente cânon romântico, de outro lado.

De fato, Gonzaga esboçou também uma arte poética. $\mathrm{Na}$ Lira I, falando a Marília, enaltece-se e enaltece sua poesia no tom coloquial, diga-se entre parênteses, distintivo da poesia ircade, mas, na segunda estrofe, põe o seguinte:

$$
\begin{aligned}
& \text { Eu vi o meu semblante numa fonte: } \\
& \text { Dos anos ainda não está cortado; } \\
& \text { Os Pastôres que habitam êste monte } \\
& \text { Respeitam o poder do meu cajado. } \\
& \text { Com tal destreza toco a sanfoninha, } \\
& \text { Que inveja até me tem o próprio Alceste: } \\
& \text { Ao som dela concerto a voz celeste } \\
& \text { Nem canto letra, que não seja minha. }
\end{aligned}
$$

Apesar do mito do pastor que fala à amada ser pura imitậ̆o dos modelos arcádicos, num ponto, pelo menos, essa estrofe jấ revela inquietação romântica. É no verso final. Ao dizer:

$$
\text { Nem canto letra que não seja minha }
$$

exprime o pastor, mais que uma atitude de superioridade menIaI, o veemente desejo de fuga à imitação. Quem assim fala î́ a a mentalidade romântica, na defesa da inspiração pessoal, di originalidade, portanto. Aliás, nesta lira, de que transcrevemos apenas uma estrofe, o sentimento amoroso, acompanhado de pena e melancolia, se integra nitidamente na escola romântlea. E o verso em questão mostra ainda que Tomás An-

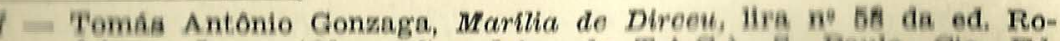

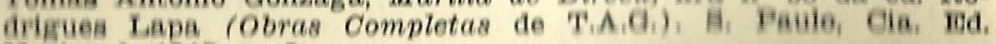
Naelonal, 1042, p. 8. tônio conscientizara o seu caso pessoal de poeta amoroso, correlacionado com as tendências vigentes na segunda metade do século XVIII.

O morbo se propagava. E antes mesmo de Araújo Pôrto Alegre e de Gonçalves Dias, aparece José Bonifácio de Andrada e Silva. O Patriarca, tão bom patriota quanto mau poeta, vem elaborar também uma arte poética para uso próprio. No prefácio às suas Poesias, publicadas em Bordéus (1825), anota:

"Fui nêles [os versos] assaz parco em rimas, porque a nossa bela língua, bem como a inglêsa, espanhola e italiana, não precisa, absolutamente falando, do zum-zum dos consoantes para fixar a atenção e deleitar o ouvido; basta-lhe o metro e ritmo; e quanto à monotônica regularidade das estanças, que seguem à risca franceses e italianos, dela às vêzes me apartei de propósito, usando da mesma soltura e liberdade, que vi novamente praticadas por um Scott e um Byron, cisnes da Inglaterra. Devo prevenir-te também, para descargo de minha consciência, que se de antemão não tiveres saboreado as poesias, que fazem a parte estética da antiga coleção hebráica, a que damos hoje o nome de Antigo Testamento; ou folheado as composições gregas e latinas, que nos restam; ou pelo menos os cantos da soberba Albion, e da Germânia culta, certo não acharás o menor sabor e pico nos que ora te ofereço. Quem folgar de Marinismos e Gongorismos ou de Pedrinhas no fundo do ribeiro, dos versejadores nacionais de freiras e casquilhos, fuja desta mingoada rapsódia, como de febre amarela". ${ }^{8}$

Nicolau Tolentino (1740-1811), contemporâneo do $\mathrm{Pa}$ triarca, exprime do outro lado do Atlântico, na sátira O Bilhar, profundo desprêzo pelos imitadores da ode pindárica:

$$
\begin{aligned}
& \text { Debalde - diz - o povo vil, perverso } \\
& \text { Sôbre mim descarrega tiros rudos, } \\
& \text { que eu não só sou poeta desde o berço, } \\
& \text { mas também tenho sólidos estudos; } \\
& \text { sei que sílabas leva cada verso } \\
& \text { e não misturo graves com agudos; } \\
& \text { rompi oiteiros em Sant'Ana e Chelas, } \\
& \text { chamei "sol" à prelada, às mais, "estrêlas". }
\end{aligned}
$$

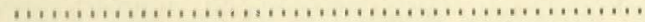

A - Américe misiale (José Donifáclo de Andrada e sulva), Poesias, wd da Asademis Brasileira de Letrals, Rio de Janeiro, 1042. 
Co'as sonoras patavras Pindo e plectro ponho em meus versos locução divina, e sei, para cumprir as leis do metro, quanto a história das fábulas me ensina; sei que dos céus tem Júpiter o cetro, que nos infernos reina Proserpina; $\grave{a}$ madrugada sempre chamo aurora, sempre chamo a um jasmim "mimo de Flora"."

Filinto Elísio, na epístola poética dirigida a José Maria de Brito, cêrca de trinta anos antes, havia postulado a volta ao modêlo clássico, mediante o enriquecimento verbal, como se 0 ato de amontoar palavras vistosas devesse conduzir, necesaâriamente, à eficácia da expressão. Sua receita é esta:

Varia, estrema a frase mais venusta, Com que dote de esplêndida riqueza

De seu discurso a intrépida estrutura. Que é soberbo Palácio um bom Poema, Cuja Fachada, Camarins, e Salas Com régia pompa ser ornados pedem. O ouro e o matiz das sêdas e pinturas, Dos cofres mais recônditos da língua Os tira à luz o próvido Poeta. Vocábulos, efígies dos objetos,

Que Camões, que Vieira memoraram, Que informe pó cobre hoje. Se erudita Mão th'o sacode, $e$ as cãs remoça ativa, Com língua rica aditará à Elísia. ${ }^{10}$

Isto que acabamos de ler chega a ser inconcebível, como arte poética, justificando a crítica mordaz de Tolentino. Mas nho hâ como pedir agilidade e frescura de espírito ao pesado e indigesto Francisco Manuel do Nascimento.

Voltemos ao Brasil.

Ao iniciar-se, entre nós, o Romantismo, a célebre polêmica obbre a "Confederação dos Tamoios" assinala de algum modo

1) Nieolau Tolentino, Satiras. 2" ed. Selegâo, pref, e notas de Rodri

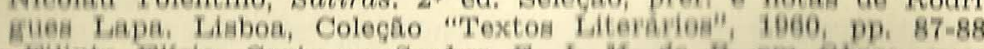

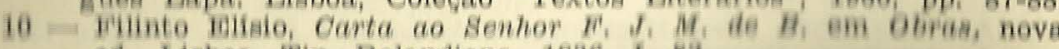
edi, Liabos, Tip. Rolandians, $1836, i_{1}$, os rumos perseguidos instintivamente pelos românticos da primeira hora. O rio-grandense Manuel de Araújo Pôrto-Alegre, por exemplo, tomando ali o partido do Visconde de Araguaia, conceituou o poema épico como um "fato moral", lição genuìnamente clássica, com o que teve o mérito de enfurecer ao jovem José de Alencar. ${ }^{11}$ De qualquer modo, a discussão não trouxe à tona qualquer conceito de excepcional importância. O patos romântico - se é que isto explica alguma cousa - uniformizara e etiquetara nossos primeiros autores, impondo-lhes a mesma bitola. Apesar disso, isto é, embora não teorizassem, tais autores - seguindo simplesmente a lição européia e norte-americana - souberam erguer grandes construções: forjaram uma linguagem diferente, que nos persegue até hoje; nobilitaram o tema do "primitivo" como expressão do Brasil; plasmaram uma "colocação" em que o som e a afetividade se reúnem ao abrigo das tônicas, etc. etc. (Deixemos de lado os exemplos, para não alongar a extensão desta palestra.)

Com os primeiros parnasianos, fêz-se de nôvo particularmente aguda a preocupação da forma clássica. É o que se acha traduzido por Bilac na conhecidíssima Profissão de $F \dot{e}$, poesia que traz a data de 1886:

Invejo o ourives quando escrevo: Imito o amor

Com que êle, em ouro, o alto relêvo Faz de uma flor.

Imito-o. E, pois, nem de Carrara A peara firo:

$O$ alvo cristal, a pedra rara, $O$ onix prefiro. ${ }^{12}$

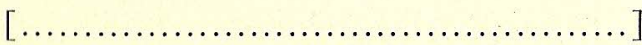

Corre; desenha, enfeita a imagem, A idéia veste:

Cinge-the o corpo a ampla roupagem Azul-celeste.

Torce, aprimora, alteia, lima A frase; e, enfim,

11 - Vi José Aderaldo Castelo, A Polemioa sôbre "A Confederação dos Tamolos". S, Paulo, Ed. da Fac, de Filosofia, Ciencias e Letras da $U_{1} \mathrm{~B}, \mathrm{P}_{1} 1058$.

13 - Nota de Manuel Bandeira: "O poeta acentuava ondo na ultima sillaba", 
No verso de ouro engasta a rima,

Como um rubim. ${ }^{1}$

Os modernistas de 22, adeptos da maior liberdade formal, cobriram de apôdo e de sarcasmo o purismo de Bilac. Mas o autor de Tarde, com esta poesia-manifesto, além de resumir 0 Ideal de arte dos parnasianos, teve outro mérito, não pequeno. Lancou essas estrofes, como um petardo, no arraial em que estanciavam os pregoeiros da "Idéia Nova" em poesia. Explico. Antes da Abolição e da República, Martins Júnior, Sílvio Romero, Damasceno Vieira e tantos outros maus poetas quiseram trunsformar a poesia em caudatária, ou melhor dito - em eserava dos partidos políticos, das seitas religiosas, das concepcồ cientificas. Entendo, por isso, que escrevendo a Profissão de Fé em 1886, como já disse, o grande poeta reivindicou em hora oportuna, quando descambávamos no mau gôsto mais palavroso e infeliz, a preeminência da forma. E isto salvou o liHismo brasileiro dos teóricos da Escola do Recife, que teimavam em armar no campo da poesia sua inimiga mortal: a Idéia, com I grande, abstração do cientificismo da época, a cousa mais Fenulnamente anti-poética até então inventada pela mente humana.

Os simbolistas brasileiros, seguindo passivamente o modelo europeu, pouco teorizaram a respeito, ao contrário do que sucederia durante a fase combativa do Movimento Modernista.

Efetivamente, em nenhuma fase literária, como na modernista, a poesia foi tão discutida. Raro é o autor do periodo (falo dos maiores) que não o tenha feito, às vêzes em diferentes oportunidades, para explicar o seu próprio comportamento dinnte das inovacões pretendidas. Numa atmosfera marcada, como a de 1922-1930, por diversos tipos de experiência, senHa-se cada um obrigado a dizer ao que vinha. Nunca houve, conseguintemente, tantos heterodoxos entre nós, como naquelę đlas em que Mário de Andrade fazia da livre pesquisa a 校 âfia de bravura. Era um nôvo romantismo que se espalhava pelo Brasil todo, talvez mais necessário que o antigo, mais original, pelo menos. Principalmente porque a sua fundamentacho, o objetivo que o definia se entende mais com a vida humana, abrangendo o homem na sua totalidade.

13 - Olave Bilac, Profisado de Fe, poesia, Apud Manuel Bandeira,

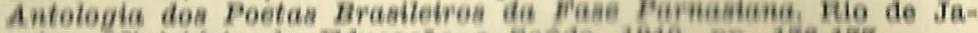

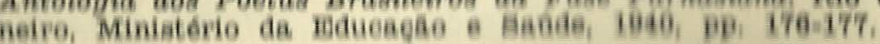

Não será, talvez, exagerado dizer-se que tivemos, daí para cá, tantas artes poéticas quantos foram os autores de bons livros. Exemplificando: Mário de Andrade - o prosador, o poeta, o epistológrafo - debateu longamente os problemas inerentes à poesia do século XX. N'A Escrava que não é Isaura, livro onde mais ágil e tumultuàriamente expôs suas intuicões, escreve:

"O assunto-poético é a conclusão mais anti-psicológica que existe. A impulsão lírica é livre, independe de nós, independe da nossa inteligência. Pode nascer de uma réstea de cebolas [e aí está, dizemos nós, nas Odas Elementales, Pablo Neruda que vem confirmar a palavra de Mário] como de um amor perdido. Não é preciso mais "escuridão da noite nos lugares ermos", nem "horas mortas do alto silêncio", como requeria Eurico - homem esquisito que Herculano fêz renascer nos idos hiemais de um dezembro romântico $[\ldots]$ Mas não se perca o assunto: a inspiração surge provocada por um crepúsculo como por uma chaminé matarazziana, pelo corpo divino de uma Nise, como pelo divino corpo de uma Cadillac. Todos os assuntos são vitais. Não há temas poéticos. Os modernistas derruindo êsses alvos mataram o último romantismo remanescente: o gôsto pelo exótico". ${ }^{14}$

Mário queria, em última análise, o mesmo que Alain veio a reclamar, alguns anos mais tarde, no Propos de Littérature, isto é, um "ritmo vital", apreensão da realidade interior e exterior em tôda a sua energia simples, e, afinal, pungente. ${ }^{15} \mathrm{Na}$ filosofia moderna, o Vitalismo, Bergson com a intuição, o próprio Existencialismo, levam à concepcão da arte como uma justaposição à realidade, ou como diz mais precisamente Jean-Paul Sartre, ao "prolongamento da nossa própria subjetividade".

O grande chefe do Modernismo não temia inovar, convicto como se achava de que a realidade Arte se impõe ao homem - como queria Benedetto Croce - por via da intuição. Daí, talvez, o hermetismo sempre implicito do produto ar-

14 - Mário de Andrade, A Escrava que não é Isaura. S. Paulo, Tip. Paulista, 1925 , pp. $24-25$.

15 - "Le poète n'a pas d'abord une pensée; il vit, il sent, selon un certain régime, salutaire, convenable à la forme humaine. De ce rythme vital il part, et, ne laissant jamais fléchir, il appelle les mots, il les ordonne d'aprés l'accent, le nombre, le son; c'est ainai qu'il découve sa pensée. Et cela ne serait point possible s'il a'y avait, en tout langage, des harmonies cachees entre le son t le sens, Cette fol au langage est la foi propre au poéte". Alain, Propos de Littorature, Paris, Paul Hartmann, 1947, p. 13. Coeteau acentua o dinamismo da palavra: "La poésie, au lieu voeables." - Le Diseours d'Ooford, Paris, Gallimard, 1056, p. 15. 
Uistico. Mas tal hermetismo, antes de ser, segundo ocorre em muitos casos, índice de impotência criadora, ou de puro despistamento (quando não de melancólico disfarce dos mascarados da vida), tal hermetismo, grande ou pequeno, acompanha sempre a poesia, integra-se em sua natureza simbólica.

Luís de Góngora, fazendo a traslação da poesia clássica a0 processo contemporâneo, foi hermético - e nesse sentido de descobridor também o foram Elliot, Valéry, Fernando Pes104, para citar apenas três dos maiores. Poder-se-ia talvez dizer que o hermetismo de tais autores representa o estágio de uim renascimento lírico extremamente fertilizador, que não produzlu ainda tôdas as suas conseqüências.

O Modernismo, porém, admitia tôdas as modas, tendêncin: ou correntes. Se a poética de Mário de Andrade atirava flechas a muitos alvos, a de outros modernistas se conformava com propósitos mais modestos, talvez mais propícios à criação enquanto obra de arte bem acabada.

Manuel Bandeira, o São João Batista do Modernismo, 酯sundo a alcunha que lhe deu o próprio Mário, aparece na tenda dos iconoclastas de São Paulo sem se envergonhar da herança simbolista.

A sua arte veio assim: feita de nuvem, de fumo, de nada. Guer chorar, vergado ao pêso da vida. Orgulha-se do seu denamparo. E propõe aos seus leitores uma arte poética amassada eom sofrimento e lágrimas:

\section{Desencanto}

Eu faco versos como quem chora De desalento... de desencanto... Fecha o meu livro, se por agora Não tens motivo nenhum de pranto.

Meu verso é sangue. Volúpia ardente... Tristeza esparsa... remorso vão... Dói-me nas veias. Amargo e quente, Cai, gôta a gôta, do coração.

E dêstes versos de angústia rouca Assim dos lábios a vida corre. Deixando um acre sabor na boca. - Eu faco versos como quem morre to

16 - Manuel Bandeira, Poesias, $0^{4}$ ed, Hie de Jaheiro, Liv, Jose olmple toditors, 1055, D.
Isto, em 1912. De súbito, anunciando o pé-de-vento do Modernismo, renasce o poeta para atitudes batalhadoras. E surge Os Sapos, poema-sátira que atingiu em cheio os ultra-parnasianos, ainda reunidos, quando do aparecimento dessa obra-prima, em tôrno de Bilac, no ano preciso de sua morte (1918). A intenção mordaz não esconde, porém, o sentimento premonitório de que uma nova arte poética andava no ar:

\section{O sapo-tanoeiro, \\ Parnasiano aguado, \\ Diz: - "Meu cancioneiro \\ E bem martelado. \\ Vêde como primo \\ Em comer os hiatos! \\ Que arte! $E$ nunca rimo \\ Os têrmos cognatos. \\ O meu verso é bom \\ Frumento sem joio. \\ Faco rimas com \\ Consoantes de apoio.}

Vai por cinqüenta anos

Que thes dei a norma:

Reduzi sem danos

A fôrmas a forma". ${ }^{1 \gamma}$

precisamente a que o movimento de 22 viria colocar sob o estandarte da mais absoluta liberdade formal. O que deu ensejo ao pronunciamento de Ronald de Carvalho, num verso pôsto como epigrafe em seus livros e que pode convir a todos os modernistas:

\section{Cria livremente o teu ritmo. ${ }^{18}$}

Mas já é tempo de falarmos em Ribeiro Couto, cuja inHuência sôbre os novos, de 1922 até os anos de 1930, foi de extraordinária significação. Não avaliaremos devidamente a

17 - Manuel Bandeira, Os Sapos, em Poesias, $6^{9}$ ed., cit., pp. 85-86. 1 . Monald de Carvalho adotou étase verso como epigrafe de seus ailimos livros de poesis 
Impulsão experimentada pela poesia menineira, nem o desenvolvimento do Penumbrismo, ambas as correntes muito atuan tes nos anos de 1925-1928, se omitirmos a contribuição que thes trouxe Ribeiro Couto. Meigo e nostálgico, é êle quem aborda com mais insistência, na sua geração, o enfermiço, a deliqüescência, os ambientes típicos das cidades antigas ou das velhas ruas das grandes metrópoles como o Rio de Janeiro e Lisboa, os interiores domésticos da pequena burguesia, as horas de lassidão e desencanto. A auto-crítica do poeta claramente o reconhece:

\section{Surdina}

Minha poesia é tôda mansa.

Não gesticulo, não me exalto...

Meu tormento sem esperança

tem o pudor de falar alto.

No entanto, de olhos sorridentes,

assisto, pela vida em fora,

à coroação dos eloqüientes.

É natural: a voz sonora

inflama as multidões contentes.

Eu, porém, sou da minoria.

Ao ver as multidões contentes

penso, quase sem ironia:

"Abençoados os eloquientes

que vos dão tôda essa alegria".

Para não ferir a lembrança

minha poesia tem cuidados...

$E$ assim é tão mansa, tão mansa,

que pousa em coraçóes magoados

como um beijo numa criança. ${ }^{19}$

No poema $A$ invenção da poesia brasileira, do livro Um Ilomem na Multidão (1926), Couto volta a ferir o tema da inainalidade dos nostálgicos, vencidos pelos discursadores, o que fas graclosamente, numa espécie de dar-de-ombros à doutrinacâ้ em favor da eloqüência e do ruído. ${ }^{20} \mathrm{Mas}$, no essencial da sua obra, Ribeiro Couto, recentemente desaparecido, pertence A linha neo-casimiriana. Em nossa literatura, tão colorida,

10 - Mbeiro Couto, Poometos de Ternura e de Melanoolia. S. Paulo,

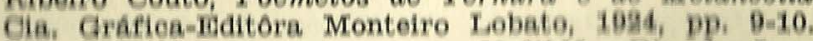

$30-V_{1}$ autor eft, Um Homem na Mullidat Hile de faneiro, Odeon, 1020. amante das frases redondas (herança fradesca de que tarda a libertar-se), a poesia dêsse sensitivo, que "tinha o pudor de falar alto", se acha contudo bem situada. É um dos bons poetas do Brasil, desprezado muitas vêzes, como o foi Casimiro, em nome da equívoca "poesia social", que em nossos dias segue 0 mau exemplo dos Martins Júnior do século XIX.

Augusto Frederico Schmidt, até então desconhecido, teve muito cedo a intuição de que o nacionalismo poético de 22 tombara finalmente, à fôrça de repetido, na mesmice irreparável:

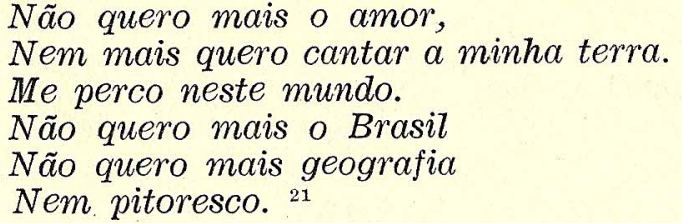

Com êstes versos iniciais do Canto do Brasileiro, fixou Schmidt em 1928 sua repulsa a certo ufanismo estreito e limitador. Do ângulo temático, o famoso poema equivale, por isso mesmo, a uma arte poética genuína, aparecida no momento exato. Seu autor foi sempre um homem de iluminações, e nos versos dessa ruidosa estréia fêz mais do que traçar um roteiro a si mesmo, abriu lugar à revisão do processo poético da idade heróica do Modernismo. E caberia dizer ainda: o lírico, o jornalista, o político, até mesmo o homem de negócios - todos os ativos heterônimos de Schmidt conduziam o pensamento e a sensibilidade ao grande mar do tempo, quero dizer, ao universal.

Mas Augusto Frederico Schmidt voltaria ainda, pelo menos em três bons poemas - A Poesia está abandonada, Ars poética e Mensagem aos poetas novos - a preocupar-se tanto com as questões formais como com as que dizem respeito substancialmente ao conteúdo da lírica e também à posicãc dela no espaço histórico. $\mathrm{E}$ assim cantou:

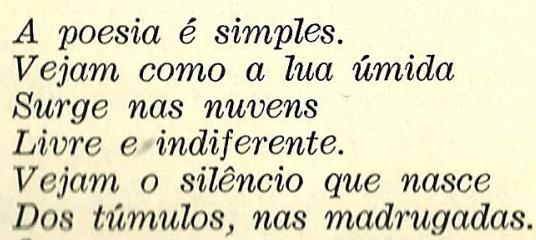

11 - Auguato Frederico SEchmidt, Canto do Brasileiro, publicado em

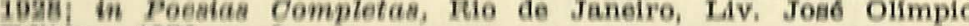

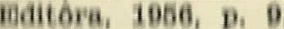


Agora sei que é simples a poesia E que é a própria vida:

Antes julgava apenas que era morte Quando nada vivera e nada sentira

Senão o desfolhar das aleluias. ${ }^{22}$

A esperança, ainda que molhada em lágrimas, era conatural ao gênio de Schmidt, em cuja obra há traços messiânieos, de poeta iluminado que se empenha em salvar a humanidade:

A necessidade de ser poeta é funda e poderosa, Nesta hora em que a Poesia vai morrer para [o mundo,

Em que a Poesia está errante, sem lar, desa[brigada,

Sem poder melhorar o mundo, sem poder sal[var o mundo,

o pobre mundo, escuro e triste,

Que os ventos do desespêro dominaram e per[deram! 23

Mas teremos de voltar, agora, a Manuel Bandeira, que nog anos de 30 irrompe com a sua Poética:

Estou farto do lirismo comedido

Do lirismo bem comportado

Do lirismo funcionário público com livro de ponto expediente protocolo e manifestações de aprêco ao sr. diretor

Estou farto de lirismo que pára e vai averiguar no dicionário o cunho vernáculo de um vocábulo

Abaixo os puristas

Todas as palavras sobretudo os barbarismos universais

Tôdas as construções sobretudo as sintaxes de exceodo

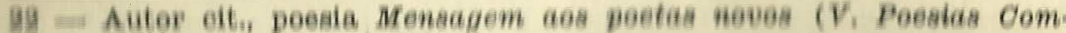
pletä, elti, pD, $700-710)$

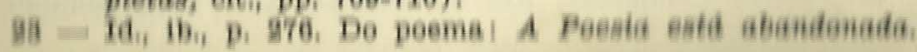

Todos os ritmos sobretudo os inumeráveis.

Estou farto do lirismo namorador

Politico

Raquítico

Sifilitico

De todo lirismo que capitula ao que quer que [seja fora de si mesmo

De resto não é lirismo

Será contabilidade tabela de co-senos secretário do amante exemplar com cem modelos de cartas e as diferentes maneiras de agradar às mulheres, etc.

Quero antes o lirismo dos loucos

O lirismo dos bêbedos

O lirismo dificil e pungente dos bêbedos

o lirismo dos clowns de Shakespeare

Não quero mais saber do lirismo que não é Tibertação. ${ }^{24}$

um pouco tardiamente, aliás, porque essa formulacão fôra já posta por muitos autores, desde a primeira hora da Semana de Arte Moderna, em 1922.

Contudo, a conjuntura histórica (30 é o ano da rebeldia armada que sai à rua e assume o poder) facilitou a difusão dêsse poema.

O lirismo que não é libertação

tem a eficácia das fórmulas. O seu enunciado consolida a doutrina de um decênio de pregação revolucionária no campo da estética. E no momento em que Bandeira o publica é quando justamente se afirma em livro uma geração de grandes poetas - Carlos Drummond de Andrade, Murilo Mendes, Jorge de Lima, Augusto Meyer.

Em Portugal, que comparte com essa geração o desgôsto das velhas fórmulas, dá-se o mesmo, isto é, em 30 também se consolidn o Modernismo português, com a geração de Presenea, continuadora, por um lado, e fixadora, por outro, das tendenclas manifestadas na Orpheu. Fernando Pessoa, sintese e

94 Poetiea fol publieado em Liberthagem ( $V_{1}$ autor eitn Posaias) 
modelo de todos, cria em 1932, após ter realizado uma grande obra, a sua arte poética "póstuma", quer dizer, a que viria reaumir tudo quanto até ali havia feito.

\section{Autopsicografia}

O poeta é um fingidor.

Finge tão completamente

Que chega a fingir que é dor

$A$ dor que deveras sente.

E os que lêem o que escreve

$\mathrm{Na}$ dor lida sentem bem,

Não as duas que êle teve,

Mas só a que êles não têm.

$E$ assim nas calhas de roda

Gira, a entreter a razão,

Esse comboio de corda

Que se chama o coração. 25

Estas estrofes, fixando em poesia o mecanismo interno do ato criador, elevou a um ponto alto o lirismo de nossa lín741. Traduz Pessoa algo mais do que um estado de espírito individual: projeta para a eternidade uma concepção metaIiliea da Poesia, linguagem das linguagens.

No estudo que se fizer, abrangendo em profundidade tôAa a poesla de lingua portuguêsa, neste século, ter-se-á que levar obrigatòriamente em linha de conta as peculiaridades douirinals, a consciência artística tão vigilante dos poetas contemporâneos, que se auto-analisam com implacável lucidez, ao mesmo tempo que sabem abandonar-se à criação, deixando falar o primitivo oculto em todo ser humano.

Neste ponto, somos obrigados a convir em que a contribuicho da psicologia, notadamente a partir de Bergson e de 1Feud, A elaboração e interpretação da obra de arte, em lugar de eircunscrever o papel da realidade na eclosão da poesia, parece que a ampliou desmedidamente. Michel Kornfeld, siiundo o ser humano no seu isolamento em face do mundo, abaervou que tal isolamento é bem maior do que se crê:

"O mundo dos fenômenos não reflete senão uma pequena parte do que existe e que a nossa consciência pode discernir pela fenda estreita de nossos sentidos. Nossa consciência re-

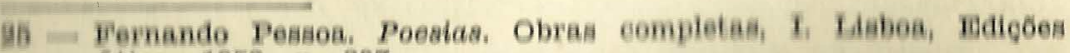
A16en, 1059, D, 297 gistra êsses sobejos àvidamente, porque aspira ao contacto com a realidade. O fenômeno que chamamos êxtase semelha uma espécie de curto-circuito, que não se produz senão raramente. O êxtase é uma revelação acêrca da essência das cousas. E um ponto efêmero que, acima dos dados da consciência, nos traz algumas parcelas da realidade supra-sensivel". 26

Não importa, porém, o grau dessa realidade; sensivel ou supra-sensível, é sempre para ela que tende a poesia. Ou como diz Pedro Salinas: "A poesia opera sempre com a realidade. $O$ poeta coloca-se diante dela como um corpo humano diante da luz, a fim de criar alguma coisa mais, uma sombra. [ . . ] $O$ poeta traz sombras ao mundo, sombras luminosas e brilhantes como luzes novas. Tôda poesia opera sôbre uma realidade, pelo gôsto de criar uma outra." 27

A arte poética de Fernando Pessoa, expressa naquele poema ( $O$ poeta é um fingidor), deslinda o enrêdo, só que o faz criando outro enrêdo, êste mais belo, porque as suas malhas são a essência mesma da poesia. Mas, para prender a fugitiva, precisamos da armadilha das palavras.

$E$ aí é que surge a arte poética de Carlos Drummond de Andrade. Malicioso e sensível, o itabirano surpreende em têrmos de lirismo a dinâmica interior da mesma criação lírica. Vejamos:

\section{O Lutador}

Lutar com palavras

é a luta mais vã.

Entanto lutamos

mal rompe a manhã.

São muitas, eu pouco.

Algumas, tão fortes

como um javali.

Não me julgo louco.

Se o fôsse, teria

poder de encantá-las.

Mas lúcido e frio,

apareço e tento

apanhar algumas

para meu sustento

num dia de vida.

Deixam-se enlaçar,

26 - Michel Kornfeld, L'Rnigme du Beau. Paris, Presses Universitaires, 1941, Di 176.

97 - Hatelo Marting, Pedro Balinas (Tinsaio sobre aua posia amo

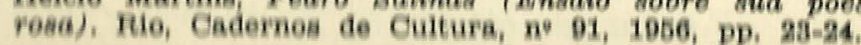


tontas à carícia

e súbito fogem

e não há ameaça

e nem há sevícia

que as traga de nôvo

ao centro da praça.

Insisto, solerte.

Busco persuadi-las.

Ser-thes-ei escravo

de rara humildade.

Guardarei sigilo

de nosso comércio.

$\mathrm{Na}$ voz, nenhum travo

de zanga ou desgôsto.

Sem me ouvir deslizam,

perpassam levíssimas

e viram-me o rosto.

Lutar com palavras

parece sem fruto.

Não têm carne e sangue...

Entretanto, luto.

Luto corpo a corpo,

luto todo o tempo,

sem maior proveito

que o da caça ao vento.

Não encontro vestes,

não seguro formas,

é fluido inimigo

que me dobra os músculos

e ri-se das normas

da boa peleja.

Iludo-me às vêzes, pressinto que a entrega

se consumará.

Já vejo palavras

em côro submisso,

esta me ofertando

seu velho calor.

outra sua glória

feita de mistério,

outra seu desdem

outra seu olume. e um sapiente amor

me ensina a fruir

de cada palavra

a essência captada,

o sutil queixume.

Mas ai! é o instante

de entreabrir os olhos:

entre beijo e bôca

tudo se evapora.

O ciclo do dia

ora se consuma

$e$ o initil duelo

jamais se resolve.

O teu rosto belo,

ó palavra, esplende

na curva da noite

que tôda me envolve.

Tamanha paixão

e nenthum pecútio.

Cerradas as portas,

a luta prossegue

nas ruas do sono. ${ }^{28}$

Esse belo poema convida ao exame, à revisão conceitual da técnica. Que é que postula? Vejamos isso mesmo em têrmos prosaicos:

Nêle está expresso que a elaboracão poética não deixa margem a tréguas prolongadas; é uma luta sem quartel: a luta sintática. Porque a palavra, inimigo impalpável, não se deixa ferir inteiramente. E por isso a peleja é sempre desigual; o artista, limitado, vê-se diante da palavra virtualmente ilimitada no seu poder. Estranha operação, em que procuramos atingir as "franjas" da palavra - como diria João Ribeiro, - o que elas têm de mais delicado e fugidio. Inimiga versátil, manhosa e pérfida, não se deixa ver de todo, não se desnuda, nem a poder de agrado, nem de violência. Assim, cansado de lutar, nem nas horas de sono o poeta depõe as armas, porque a luta prossegue no seu subconsciente.

Ora bem, isto que Carlos Drummond de Andrade exprime de modo tão eficaz parece ser a projeção, em nosso tempo, dos

28 - Carlos Drummond de Andrade, Sentimento do Mundo (V. Fazendeiro do Ar a Poesia ate Agora, Rio de Janeiro, Liv, J, Olimpio

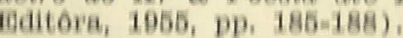


problemas de ordem estética com os quais se defrontou em especial a geracão ultra-simbolista, ou melhor, para usarmos o têrmo adequado - "decadista". Um dos críticos do fim do século, Paul Bourget, como nos lembra Álvaro Júlio da Costa Pimpão, a propósito de Eugênio de Castro, ${ }^{29}$ fisgou no estilo "decadista" algo que nos interessa verificar agora, dado que a passagem do "tema" à "palavra", como índice de preocupação do poeta, começou a dar-se com o Simbolismo. Os modernistas, ainda ai, foram herdeiros de Mallarmé e Verlaine. Cousa semethante ocoreu na pintura - a côr passou a ser mais importante do que o assunto, a contar dos impressionistas.

A tese de Bourget, sôbre o estilo "decadente", vem esbocada nos Essais de Psychologie Contemporaine:

"Par le mot de décadence, on désigne volontier l'état d'une société qui produit un trop petit nombre d'individus propres aux travaux de la vie commune. Une société doit être assimilée à un organisme. Comme un organisme, en effet, elle se résout en une fédération d'organismes moindres, qui se résolvent eux-mêmes en une fédération de cellules. L'individu est la cellule sociale, Pour que l'organisme total fonctionne avec énergie, il est nécessaire que les organismes moindres fonctionnent avec energie, mais avec une énergie subordonnée, et, pour que ces orranismes moindres fonctionnent eux-mêmes avec énergie, il est nécessaire que leurs cellules composantes fonctionnent avec énerte, mais avec une énergie subordonnée. Si l'énergie des cellules devient indépendante, les organismes qui composent l'organisme total cessent pareillement de subordonner leur énergie à l'energie totale, et l'anarchie qui s'établit constitue la décadence de l'ensemble. L'organisme social n'échappe pas à cette loi. II entre en décadence aussitôt que la vie individuelle s'est exaférée sous l'influence du bien-être acquis et de l'hérédité. Une même loi gouverne le développement et la décadence de cet autre organisme qui est le langage. Un style de décadence est celul oú l'unité du livre se décompose pour laisser la place à l'indépendance de la phrase, et la phrase pour laisser la place A l'indépendance du mot. Les exemples foisonnent dans la littérature actuelle qui corroborent cette hypothése et justifient eette analogie". so

99 - Alvaro Júlio da Costa Pimplio, Gente Grada, Coimbra, Atlantida, 1952, p. 167

10 - Daul Bourget, Dasais de Payehologie Contemperaine, $I_{4}$ Paris Flon, 1910, pp, $10-20$,
Isto de se considerar a linguagem como organismo vivo lembra a melhor doutrina naturalista. Mas, afora qualquer prejuízo de escola, Bourget tem razão no que concerne à segunda parte, ou seja, quando observa que, no Decadismo, o que existe, antes de tudo, é o isolamento da palavra, ou, para usarmos a terminologia saussuriana, sua valorização através do significante.

Nos casos comuns de comunicação, não falamos por palavras, mas por meio de "massas elocutivas". Não fazemos poe mas com palavras, mas com palavras situadas, colocadas, combinadas, de modo que o liame sintático, sonoro, ou visual (e abro aqui várias janelas ao Concretismo) - são diversos os instrumentos de ligação, - é quem comanda o efeito final. O sentido, aquilo que se quer compreender na prosa, ou se quer sentir na poesia, vem dessa colocação. Palavra isolada, - em "estado de dicionário", como diz o poeta, - é palavra dormindo, sentido virtual, energia não desperta.

A esta altura de nosso trabalho, podemos tirar uma conclusão. A de que, no século XX, se tem impôsto aos poetas de língua portuguêsa, e, entre êles, até mesmo aos espíritos menos inclinados à dialética, a discussão apaixonada da poesia, quer do ponto de vista conceitual, quer no que respeita a várias técnicas.

E O que acontece com Ribeiro Couto:

\section{Brincadeira}

Poetas há

Que não compreendem nada fora do que êles [chamam escola.

Fazem versos como os remendões batem sola. Batem sola! Batem sola!

E começam: "O céu, imenso, a arder, é uma [imensa corola,

Ta ra ta ra ta ti, ta ra ta ra ta tá”. "31

Cassiano Ricardo, cuja obra documenta uma ardente inquietaçáo, ainda hoje, passados os seus setenta anos de vida, continua perplexo diante do mistério da palavra. No seu úllimo livro, Jeremias sem-chorar (1964), volta a perguntar-se, em dols tempos:

31 - Hibeiro Couto, Poesias Reundas, Rio, Liv, José Olimplo Editóre, 1060, Di 111 


\section{Poema}

1

$$
\begin{array}{r}
\text { Que é a Poesia? } \\
\text { uma itha } \\
\text { cercada } \\
\text { de palavras } \\
\text { por todos } \\
\text { os lados. }
\end{array}
$$

2

Que é o Poeta? um homem que trabatha o poema com o suor do seu rosto. Um homem que tem fome como qualquer outro homem. ${ }^{32}$

Outra conclusão é que parece caminharmos para a desliteratizacão da poesia. Para uma poesia despojada de galas, enfeites e sons arranjadinhos. Poesia não "literária", delumanização da arte, na fórmula de Ortega y Gasset, uma vez que "poesía no es naturalidad, sino voluntad de amaneramiento" in

Ê o que exprime João José Cochofel, em livro de prineiplo dêste ano:

$$
\begin{aligned}
& \text { Faço poesia } \\
& \text { como quem canta ou chora } \\
& \text { se tem razões para isso. }
\end{aligned}
$$

\section{A literatura}

posso bem ignorá-ta.

Só não posso fechar

esta chaga de tume

a supurar

música, legendas, negrume,

tixo. si

19. Casiano Ricardo, Jeremias sem-chorar, Rio, Liv, José Olímpio 10đitôre, 1984, p. 11.

al af, Josi Ortega y Gasset, Espiritu de lo Letra. Madrid, Revista Co. Jos Ortega y Gusset, $105, \mathrm{pp}, 106=107$

14 foù Josd Cochofel, Quatro Andamentes, Coimbra, Caneioneiro 'Ventine', $1066, \mathrm{p}_{1}$ id.
Aí está um dos pontos capitais do lirismo contemporâneo: não se desejar lírico, como que se envergonhando da sua própria natureza. Como se ao artista, ao trabalhador do som que é o poeta, fôsse permitido dizer:

\section{A literatura \\ posso bem ignorá-la}

e continuasse a fazer versos.

Mas, sim. Êsse ignorar é também um dos requintes da técnica mais evoluída. No fingir, segundo o conceito de Fernando Pessoa, o a-literário, ou na busca do prosaísmo aparente, como em João Cabral de Melo Neto, o que encontro de marcante é o mêdo de ser demasiado humano em desfavor do literário. Vou explicar-me em seguida.

Com efeito, sabe o poeta de hoje (esta, aliás, é a sabedoria do poeta de todos os tempos) que o gôsto é cambiante e mutável. As fórmulas que êle consagra ràpidamente se desatualizam, caem na imobilidade, mas não o gôsto enquanto elemento de juízo estético, sempre dinâmico por natureza e função. E é de observar-se que, do Romantismo para cá, em virtude da extrema liberdade conseqüente ao abandono da teoria da mimese, os "estilos" se alternam e fundem num andamento extraordinàriamente rápido.

Ora, ao lado disto, há entre os modernos uma insatisfação evidente no que concerne à temática. Exemplifiquemos. $O$ velho jôgo amoroso (reflexo de fases da vida humana em que a mulher era apenas flor de gineceu), transparente como técnica de sedução nas cantigas dos trovadores medievais, deixou de ter validade por falta de objeto. O tema por excelência do homem moderno não é a luta amorosa, mas a condição carnal, ou seja, a sensacão de vazio que o assalta ao se sentir, no teatro do mundo, condenado como Sísifo. A dialética do social, a "náusea" sartreana, o "sisifismo" de Camus, a esperança de redenção claudeliana, - qualquer uma dessas posicôes, as mais responsáveis nos dias de hoje, - desaristocratiza o poeta, ser que na unicidade se quer afirmar. Ante a complexidade do pensamento moderno, o poeta se desumaniza, Isto é, envergonha-se da sua aristocracia mental, da sua dorzinha de cotovêlo, fenômeno de economia pessoal que não interessa necessariamente ao espirito competitivo, ao combate ideológico que parece marcar a nossa época com o sêlo da diseórdia.

Loge, vê-se o poeta tî́e comprometido com o social, com a multidäo, - diante da qual, jâ o vimos, Ribeiro Couto se co- 
locou tão canhestramente, - que se julga indigno sempre que fala de si, em vez de falar dos homens, dos "outros" que penam, como êle, as dores da Cidade.

$\mathrm{E}$, como a desconformidade intima do ser humano é a regra, como o seu atrito com o Cosmo representa o vinco mais original da condição humana (se assim não fôsse, não haveria santos), é lógico que o poeta não pode deixar de cantar — digo, de protestar. Pelo canto se rebela; a sua poética, "morena, preta ou azul", como aquela noiva ardentemente buscada num poema de Carlos Drummond, ${ }^{35}$ a sua poética pretende sempre uma arrumação inteiramente nova. E nessa arrumação, quero dizer: no ordenamento da matéria, o poeta converte em ato a possibilidade que the resta de ser inteiramente livre. Livre no ato de deixar fluir a escória dos dias:

\section{música, legendas, negrume,}

tixe

numa completa, desesperada condenação de tudo, inclusive do seu ofício de poeta.

Mesmo para os que não chegaram ao paroxismo da "náunea" sartreana, a situação mudou. Pressentiu-o, antes de nós, a feractio simbolista francesa, mas esta ainda atribuia imporlâncin fundamental ao som - de la musique avant toute cho, Hoje, a literatura se "desarmoniza", atinge o cerne, é maFia. Enunciou isto de forma lapidar um crítico de grande lueldez, Pierre de Boisdeffre: “... os meios de representação mudaram profundamente. A literatura melódica não é mais poasivel, eis a verdadeira revolução literária do século XX.

O Concretismo, omitindo o nexo da sintaxe, baseou-se no: sinais Ideográficos, ou, segundo preferem dizer seus adep10月, na expressão ideogrâmica, situada no espaço e desajudada, por conseguinte, dos vínculos tradicionais da linguagem comum. Críou-se um nôvo tipo de comunicação anamelódico,

$115=$ Autor elt. Alguma Poesia (V. Famendelro do Ar \& Poesia até Agera, elt, p. 64)

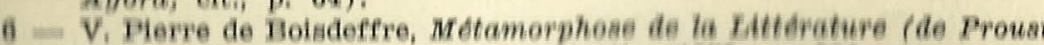

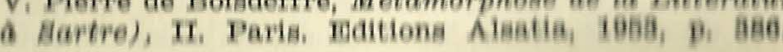

muito mais impermeável à emoção do que o hermetismo digamos - de um Mallarmé. Por isto, apesar do esfôrço de seus partidários, o movimento concretista não encontrou grande ressonância. A linguagem cifrada, despovoando-se de afetividade, cortou a ligação do leitor com o poema, e ninguém pode fugir às regras específicas do seu jôgo. Por outro lado, o Concretismo é o que se pode denominar "movimento fechado": a ortodoxia dos seus doutrinadores cerceia o campo de ação, impede o livre surto da personalidade.

Contudo, buscaram os seus adeptos um S. João Batista para o nôvo credo no grande poeta, o mais representativo da talvez impròpriamente chamada "geracão de 45": João Cabral de Melo Neto. Mas êste é um artesão admirável, sensível e lúcido, que elabora uma das poesias mais ardentes do nosso tempo - dando ao seu "discurso", pelo rigor da palavra, pela contenção do sentimento em benefício da emoção plasmada estèticamente, uma penetração que, a nosso ver, só teve igual, na poesia brasileira, em Carlos Drummond de Andrade e, na portuguêsa, em Fernando Pessoa. Com a Psicologia da Com posicão, Antiode (Contra a poesia dita profunda) e A Lição de Poesia, sobretudo essas três peças, João Cabral leva a pesquisa ao intimo da poesia, e, o que mais importa, liberta-a do excesso para salvar o que lhe é estritamente necessário. Assim:
A noite inteira o poeta em sua mesa, tentando salvar da morte os monstros germinados do seu tinteiro. Monstros, bichos, fantasmas de palavra, circulando, urinando sôbre o papel, sujando-o de seu carvão.

Carvão de lápis, carvão da idéia fixa, carvão da emocão extinta, carvão consumido nos sonhos. [

A luta branca sobre o papel que o poeta evita. Luta branea onde corre o sangue de suas veias de dgua salgada. 
A física do susto percebida entre os gestos diários; susto das coisas jamais pousadas porém imóveis - naturezas vivas.

$E$ as vinte palavras recolhidas nas águas salgadas do poeta de que se servirá o poeta em sua máquina útil.

Vinte palavras sempre as mesmas de que conhece o funcionamento, a evaporação, a densidade menor que a do ar. ${ }^{37}$

Trabalhando com a consciência artesanal de um GóngoFa, Jolio Cabral de Melo Neto tem sôbre o cordovês a vantafem de ser um homem do século XX. Quero dizer: o social da iia obra é vivaz e sincero. Compreende-se, por isso, a influêndut obra é vivaz e sincero. Compreende-se, por isso, a influenautores mais jovens, fato que se observa também em Portiigal. Com efeito, a novissima poesia portuguêsa, por meio de Alguns nomes expressivos da inquietação que por lá se obde alguns nomes expressivos da inquietação que no sua deliberada secura, um fermento renovador para o lirismo sentimental e magoado da tradição lusíada.

Mas a última criação de nossa vanguarda literária já não e日t para isso. Quer cousa mais engajada, mais conforme com of tempos de revolta em que andamos mergulhados. Assim, a revista Praxis, recentemente aparecida em S. Paulo, constelou em tôrno de Mário Chamie (1922 -), seu fundador, os inovadores da Restauração Praxis. Reconhece, porém, Mário Chamie que o Modernismo de 22 "esgotou até o presente momento qualquer possibilidade de nôvo movimento, no Brasil". 1. Acrescenta: "Revolução literária no mais largo sentido, êle, ainda, năo cerrou o seu ciclo. Sua capacidade de ação inteleclual coletiva permanece. As tentativas novas de movimento conifnuam no seu âmbito e representam tendências parciais oii retomada de sectores da sua diversificada problemática." Tor ansumida pelos concretistas, afirmando que êstes últimos se manilveram na mesma órbita do Movimento Modernista. A sa-

a7 Joâo Cabral de Melo Neto, Duas Agual, Ho de Janetro, Lu,

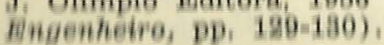

ber: "O concretismo se coloca como um apêndice num corpo maior; enfatiza, com contribuicões específicas, um aspecto da problemática aberta por 22 (palavra-coisa, combate ao discursivo, renovação da estética futurista, etc.) e dêste, por isso mesmo, não poderá pretender idêntica ação intelectual coletiva”.

Por isso, entende que chegou a hora de "os jovens intelectuais brasileiros criarem condições de uma nova ação coletiva da inteligência". Como não podia deixar de ser, afirma - poeta que deverá caber à poesia-praxis, criacão sua, esta tarefa. Postula: "O único meio para se implantar essas condições é a praxis individual, consciente e responsável do artista. O primeiro passo está em abolir a idéia de equipe-escola, de grupo cerrado em tôrno de um denominador exclusivista; de abolir, enfim, a idéia de movimento, pois esta palavra tem um compromisso literário com a negatividade de consumação metódica. Dêsse passo resultarão aquelas condições e dêle, certamente, resultará o encerramento do exaustivo e riquíssimo ciclo de 22. A literatura praxis é a única via, em nossa atual situação, de uma consequiente atividade criadora do artista. Através dela, êle se insere na órbita dos interêsses sociais e poderá, em têrmos extra-literários e em benefício da própria literatura, colaborar na efetivação de uma nova antropologia cultural que desponta".

A praxis revolucionária de Carlos Marx, pretendendo comprovar a objetividade do pensamento, atua sôbre o homem como instrumento, como acão modificadora do próprio homem. A filosofia da praxis, dentro da concepção dêsses jovens poetas, leva-os a admitir que "a literatura-praxis se estabelecerá, em definitivo, como fazer histórico, quando intelectuais e povo forem leitores de uma mesma linguagem". Isto porque "a literatura-praxis instaura um ativismo permanente; uma transformaç̃o estatística variável, anti-arqueológica. O ativismo de um poema-praxis o define: usado (consumido) é sempre o mesmo desencadeando novos usos. Mantém-se e se supera mantendo-se". Porque, em suma, o poema-praxis é isto: "fusão totalizada do ato de compor, da área de levantamento da composiçăo e do ato de consumir. Instrumento que constrói. PoeAla-producăo". Nessa ordem de idéias, estão convencidos os geus teóricos que o poema-praxis é "a única totalizacão válida e nẩo-alienada da consciência poética contemporânea", ${ }^{38}$ afir-

al $=$ V, Màie Chamle, Poema-Prasia (Manifesto Didatioo) em Lavra

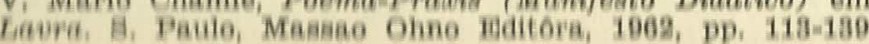


macăo arrojada de uma nova ortodoxia. Discípulos do poeta paulista, no Rio de Janeiro, afinam também pelo mesmo senilido prático: "O poema-praxis, portanto, instaura uma tensão continuada: ao contrário de um epidérmico registro marginal e maquinal da realidade, cria condições funcionais para uma orgânica, integral e serialistica abordagem dessa mesma realidade que, sendo viva e variável, lhe empresta os fatôres dinâmicos que compõem suas células, áreas e sistemas". ${ }^{39}$

\section{***}

Vamos terminar.

Afirma-se, às vêzes, que a poesia está em crise no Bra111 de hoje. Não nos parece tal. Bem ao contrário, estamos enriquecendo sensivelmente a nossa experiência poética. Poetal da primeira hora do Modernismo, como Manuel Bandeira Cassiano Ricardo, continuam em plena atividade; e, compreensivos, não desdenham as aventuras, de que é prova a producăo concretista do primeiro e a calorosa adesão dada pe6) regundo à Instauração Praxis.

Associamo-nos, assim, de diversas maneiras, ao drama ipiritual do homem contemporâneo. E, apesar do nosso subdesenvolvimento, que gera não raro, entre os mais sôfregos, impulsos de obtusa xenofobia, vamos ganhando novas formas de comportamento, que nos aproximam, por conseqüência, dia de comportamento, que nos aproximam, por consequencia, dia
i dis, do sentido dinâmico da cultura, valor universal. Nesse fogo cruzado de ideologias e sistemas, a evolução do gôsto, a maturidade intelectual, a mesma intensidade com que as formula: aparecem, desaparecem ou se transformam; a interação intural, em suma, que nunca se processou tão ràpidamente como nos dias de hoje - tudo contribui para dar à poesia um campo de luta mais largo e mais fascinante.

Jules Monnerot, num livro sempre atual, mostra como i psicologia moderna, alargando a possibilidade de explicação do mundo onírico, veio enriquecer a poesia. Esta já realizou a faeanha de arrancar dos lógicos o reconhecimento de que bode a deve coexistir com êles na República. Conquistou, aslim, eomo diz esse autor, uma verdadeira Declaração dos Diretios do Sonho,

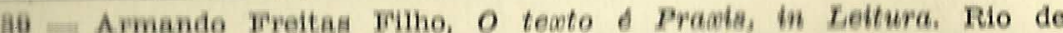

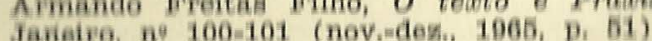

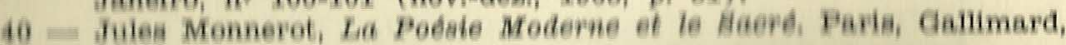
1040.
Mas, no mundo contemporâneo, o que mais avulta é o reconhecimento universal de que a poesia é a linguagem do mistério. Juan Alfonso de Baena achou que ela era "la gracia infusa del Señor Dios", formulação metafísica concorde com as suas convicções religiosas. Mário Quintana, em nossos dias, sem estar ao abrigo de tais conviccões, disse a mesma cousa:

\section{O Poema}

Um poema como um gole d’água bebido no [escuro.

Como um pobre animal palpitando ferido.

Como pequenina moeda de prata perdida pa[ra sempre na floresta noturna.

Um poema sem outra angústia que a sua mis[teriosa condição de poema.

Triste.

Solitário.

Único.

Ferido de mortal beleza.

Mas, como reconhece Adolfo Casais Monteiro, o fato de aceitarmos hoje, em grande maioria, o mistério como natureza intrínseca da criação poética, tem enormes conseqüências. Diz êle:

"Embora possa ter tomado proporções de moda, com abusos nada favoráveis a generalizar-se o seu reconhecimento, a admissão de que há um "mistério da poesia" é, seguramente, um ganho que a nossa época tem no seu ativo, e graças ao qual abriu profunda brecha na fácil presunção das "explicacões" que para tudo encontram causas, num impressionante à vontade em passar dos fatos conhecidos da vida, da cultura, da experiência do poeta para qualquer coisa verificada na sua poesia". 42

Resta dizer o principal. Vinda ou não de tão alto, a poesía é sobretudo liberdade. Se the negamos o direito de ser livremente, ai! do mundo. Pois não restará, então, uma só estrêla para lluminar o caminho.

41 - Märio Quintana, o Aprendis de Feitiooiro. Pôrto Alegre, Ediçóes Tronteira, 1050 .

49- Adolfo Casall Monteiro, A Palavra masenoial. 8 , Paulo, Cia, Editora Naelonal, $1065, p_{1} 40$ 